\title{
PEMODELAN ZONA ANGKUR GANDA DENGAN METODE ELEMEN HINGGA DAN STRUT AND TIE MODEL
}

\author{
Silvia Stefany ${ }^{1}$ dan F.X. Supartono ${ }^{2}$ \\ ${ }^{1}$ Program Studi Sarjana Teknik Sipil, Universitas Tarumanagara, Jl.Letjen S. Parman No.1 Jakarta \\ Email: silvia_stefany@yahoo.com \\ ${ }^{2}$ Program Studi Sarjana Teknik Sipil, Universitas Tarumanagara, Jl.Letjen S. Parman No.1 Jakarta \\ Email: fxsupartono@gmail.com
}

\begin{abstract}
ABSTRAK
Teknologi prategang sekarang ini sudah banyak diterapkan pada ruang lingkup teknik sipil seperti jembatan, struktur gedung, dan lain sebagainya. Faktor kunci utama dalam pembangunan struktur beton prategang terletak pada zona angkur nya. Zona angkur merupakan zona pada beton yang terjadi distribusi tegangan dari kabel prategang ke beton dimana pada zona ini gaya terpusat akibat prategang ditransfer melalui angkur ke beton lalu menyebar untuk mencapai lebih banyak distribusi tegangan linier diatas penampang dari balok pada suatu jarak dari angkur.Tegangan yang terjadi pada zona angkur dianalisis dengan menggunakan pendekatan metode elemen hingga dimana bagian-bagian struktur zona angkur dibagi menjadi elemen-elemen yang lebih kecil, sehingga didapatkan analisis yang lebih akurat. Hasil dari analisis ini menunjukkan bahwa zona angkur pada daerah tekan menimbulkan tegangan tarik pada arah lateral sehingga tegangan tarik yang terjadi perlu diatasi dengan bursting steel. Bursting steel ini kemudian didesain dengan menggunakan pendekatan metode strut and tie. Strut and tie model adalah suatu pendekatan yang digunakan untuk mendesain discontinuity regions (D-regions) pada struktur beton bertulang atau prategang.Dengan metode ini aliran tegangan yang terjadi dapat digambarkan seperti rangka batang dengan mengansumsikan retakan sebagai tekan dan tulangan sebagai tarik. Pada daerah tepi balok juga terdapat tegangan tarik spalling yang perlu diatasi dengan tulangan spalling.
\end{abstract}

Kata kunci: zona angkur, metode elemen hingga, bursting steel, strut and tie, spalling

\section{PENDAHULUAN}

Semakin meningkatnya kebutuhan pembangunan infrastruktur, maka semakin banyak pula inovasi yang diciptakan untuk mendapatkan hasil yang lebih baik dan efisien. Salah satu dari inovasi tersebut adalah teknologi prategang. Faktor kunci utama dalam pembangunan struktur beton prategang terletak pada zona angkur nya. Zona angkur merupakan tempat dimana terjadi distribusi tegangan dari kabel prategang ke beton. Hal ini membuat zona angkur menjadi daerah yang bertegangan tinggi dan kompleks, sehingga sangat berpotensi terjadi kerusakan atau keretakan. Keretakan tersebut dapat diantisipasi dengan mendesain tulangan yang sesuai untuk menahan tegangan tarik yang terjadi.

Tegangan yang terjadi pada zona angkur dapat dianalisis dengan menggunakan pendekatan metode elemen hingga. Metode elemen hingga membagi bagian-bagian struktur menjadi elemen-elemen yang lebih kecil, sehingga didapatkan hasil analisis yang lebih rinci dan akurat. Untuk mendesain tulangan sebagai penahan tegangan yang terjadi pada zona angkur digunakan pendekatan strut and tie model (STM). Metode strut and tie ini sudah banyak digunakan untuk perhitungan struktur bangunan. Dengan menggunakan metode ini, aliran tegangan dapat digambarkan dengan bentuk seperti rangka batang dengan mengasumsikan retakan sebagai tekan (strut) dan tulangan sebagai tarik (tie). Hasil yang ingin dicapai dari penelitian ini adalah desain tulangan yang dibutuhkan akibat adanya distribusi tegangan pada zona angkur dengan analisis tegangan meggunakan metode elemen hingga dan desain tulangan menggunakan strut and tie model (STM).

\section{Zona angkur (anchorage zone)}

Zona angkur atau blok ujung dapat didefinisikan sebagai volume beton dimana gaya prategang yang terpusat pada angkur menyebar ke arah transversal menjadi terdistribusi linier di seluruh tinggi penampang di sepanjang bentang. Pada balok pratarik, kabel prategang mentransfer gaya tekan ke beton sekitarnya lebih panjang dari $\mathrm{L}_{t}$ secara bertahap. Pada balok pascatarik, kabel prategang mentransfer gaya tekan langsung ke akhir dari balok lewat bearing 
plate dan angkur. Panjang daerah ini mengikuti prinsip St. Venant, yaitu bahwa tegangan menjadi seragam di lokasi sejauh kira-kira sama dengan tinggi penampang $h$ diukur dari lokasi alat angkur. Keseluruhan prisma yang mempunyai panjang transfer $h$ tersebut adalah zona angkur total.

Untuk tujuan mendesain, zona angkur dibagi menjadi zona umum dan zona lokal. Zona umum identik dengan zona angkur total yang panjangnya sama dengan tinggi penampang $h$ untuk kondisi standar. Zona lokal adalah prisma beton di sekeliling dan tepat di depan alat angkur dan mengekang penulangan didalamnya. Panjang zona lokal ini harus ditinjau sebagai yang terbesar diantara lebar maksimum atau panjang alata angkur yang mengekang penulangan.

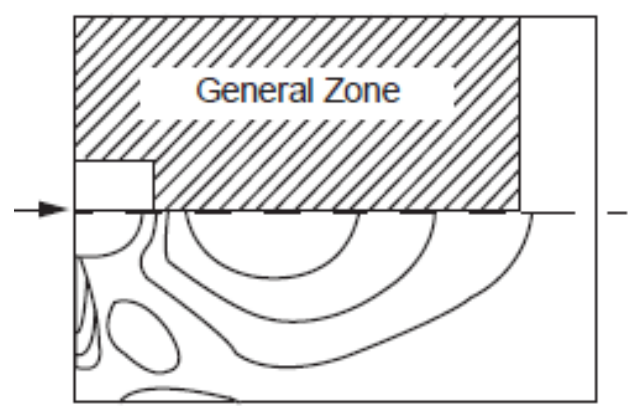

Gambar 1. Tegangan tarik utama dan zona umum pada zona angkur Sumber: AASHTO, 2011:124

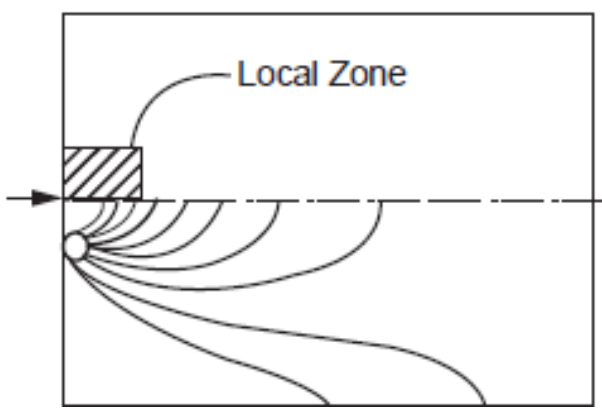

Gambar 2. Tegangan tekan utama dan zona lokal pada zona angkur Sumber: AASHTO, 2011:124

\section{Strut and tie model (STM)}

Strut and tie model adalah suatu pendekatan yang digunakan untuk mendesain discontinuity regions (D-regions) pada struktur beton bertulang atau prategang. Konsep STM didasari atas pendekatan plastisitas untuk aliran gaya di zona angkur dengan menggunakan batang-batang lurus tarik dan tekan yang bertemput di titik-titik diskret yang disebut nodal sehingga membentuk rangka batang. STM mengurangi keadaan tegangan yang kompleks pada $D$ region dari beton bertulang atau prategang menjadi sebuah rangka batang yang terdiri dari jalur tegangan uniaxial yang sederhana. Bagian dari STM yang merupakan tegangan tarik disebut ties dan mewakili lokasi dimana tulangan harus diletakkan. Mengetahui kekuatan yang bekerja pada batas-batas STM, gaya pada masing-masing anggota rangka batang dapat ditentukan dengan teori dasar rangka batang.

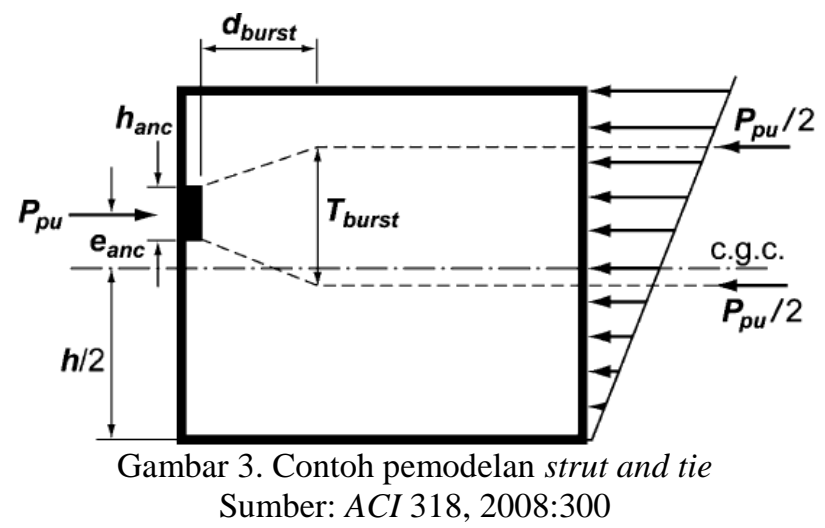




\section{Batang tekan (strut)}

Strut atau batang tekan diasumsikan sebagai beton yang kuat menahan tekan dengan memperhitungkan landasan pembebanan dan kuat efektif pada strut tersebut. Batasan tegangan tekan, $f_{c u}$, dihitung dengan menggunakan rumus sebagai berikut:

$$
\begin{gathered}
\mathrm{f}_{\mathrm{cu}}=\frac{\mathrm{f}_{\mathrm{c}}}{0,8+170 \varepsilon_{1}} \leq 0,85 \mathrm{f}^{\prime}{ }_{\mathrm{c}} \\
\varepsilon_{1}=\varepsilon_{\mathrm{s}}+\left(\varepsilon_{\mathrm{s}}+0,002\right) \cot ^{2} \alpha_{\mathrm{s}}
\end{gathered}
$$

dengan $\alpha_{\mathrm{s}}=$ sudut terkecil antara strut dan tie (derajat), $\varepsilon_{\mathrm{s}}=$ regangan tarik pada beton, $\mathrm{f}_{\mathrm{c}}=$ tegangan pada beton (MPa).

Kekuatan nominal dari strut tidak bertulang dihitung dengan menggunakan rumus sebagai berikut:

$$
P_{n}=f_{c u} A_{c s}
$$

dengan $\mathrm{P}_{\mathrm{n}}=$ kekuatan nominal dari strut $(\mathrm{N}), \mathrm{f}_{\mathrm{cu}}=$ batasan tegangan tekan $(\mathrm{MPa}), \mathrm{A}_{\mathrm{cs}}=$ luas penampang efektif strut $\left(\mathrm{mm}^{2}\right)$

\section{Batang tarik (tie)}

Tie merupakan batang tarik pada strut and tie yang terdiri dari tulangan ataupun prategang ditambah sebagian dari beton di sekelilingnya. Sebuah tie dapat terdiri dari satu atau beberapa lapis penulangan. Desain penulangan tie ini berdasarkan pada:

$$
\mathrm{T}_{\mathrm{u}} \leq \varnothing \mathrm{A}_{\mathrm{s}} \mathrm{f}_{\mathrm{y}}
$$

dengan $\mathrm{T}_{\mathrm{u}}=$ gaya tarik $(\mathrm{N}), \mathrm{A}_{\mathrm{s}}=$ luas area tie $\left(\mathrm{mm}^{2}\right), \mathrm{f}_{\mathrm{y}}=$ tegangan leleh baja $(\mathrm{MPa})$.

\section{Titik pertemuan (node)}

Node merupakan titik pertemuan dari tiga batang atau lebih dari strut and tie dengan berbagai kombinasi yang secara umum dapat dibagi menjadi empat jenis sambungan pertemuan yaitu CCC, CCT, CTT, dan TTT.

\section{Penulangan kontrol retak (crack control reinforcement)}

Penulangan ini diharapkan dapat mengontrol lebar retakan dan untuk memastikan daktilitas menjadi minimum untuk batang sehingga memungkinkan redistribusi yang signifikan dari tegangan internal. Penulangan untuk arah vertikal maupun horizontal harus memenuhi persyaratan berikut:

$$
\begin{aligned}
\frac{A_{v}}{b_{W} s_{v}} & \geq 0,003 \\
\frac{A_{h}}{b_{w} s_{h}} & \geq 0,003
\end{aligned}
$$

dengan $A_{h}=$ total area penulangan kontrol retak horizontal dengan jarak $s_{h}\left(\mathrm{~mm}^{2}\right), A_{v}=$ total area penulangan kontrol retak horizontal dengan jarak $s_{v}\left(\mathrm{~mm}^{2}\right), b_{\mathrm{w}}=$ lebar batang $(\mathrm{mm}), \mathrm{s}_{\mathrm{v}}, \mathrm{s}_{\mathrm{h}}=$ jarak vertikal dan horizontal penulangan kontrol retak $(\mathrm{mm})$

\section{Metode elemen hingga}

Metode elemen hingga adalah salah satu metode analisis yang rinci berbasis numerikal, yang sering dipakai untuk memecahkan masalah matematis dan fisika. Berbagai jenis masalah yang dapat dianalisis menggunakan metode ini adalah analisis struktur, transfer kalor, aliran fluida, transpor massa, dan medan elektromagnetik. Konsep dari metode elemen hingga adalah membagi bagian-bagian struktur menjadi elemen-elemen kecil yang tersambung pada nodal-nodal, permukaan atau garis tertentu yang disebut dengan diskritisasi. 


\section{METODOLOGI PENELITIAN}

Berikut prosedur yang dilakukan dalam penelitian ini:

1. Menentukan zona angkur pada balok prategang

2. Analisis gaya prategang

3. Analisis distribusi tegangan struktur secara 3 dimensi dengan menggunakan bantuan program MIDAS FEA 2016 v1.1

4. Menentukan letak tulangan tarik

5. Membuat sketsa strut and tie dan menghitung gaya yang terjadi pada setiap batang

6. Cek tegangan pada strut dan nodal

7. Melengkapi desain kebutuhan tulangan akibat kontrol retak

\section{HASIL ANALISIS DAN PEMBAHASAN}

Dimensi balok yang digunakan berukuran 0,4 m x $1 \mathrm{~m}$ x $15 \mathrm{~m}$ dengan asumsi perletakan sendi-sendi dan dibebani gaya luar sebesar $35 \mathrm{kN} / \mathrm{m}$ sepanjang bentang. Mutu beton (f'c) sebesar $40 \mathrm{MPa}$. Berdasarkan gaya luar yang terjadi, didapatkan jumlah strand sebesar 19 strand yang kemudian dibagi menjadi 12 strand dan 7 strand dengan eksentrisitas tengah bentang $350 \mathrm{~mm}$ dari titik berat. Angkur dengan 12 strand kemudian disebut sebagai P1 dan angkur dengan 7 strand disebut sebagai P2. Setelah dilakukan analisis gaya prategang didapatkan jacking force P1 dan P2 masing-masing sebesar 1570,73 kN dan 916,26 kN. Zona angkur diambil sebesar 1,5h sehingga didapatkan lebar zona angkur sebesar $1500 \mathrm{~mm}$.

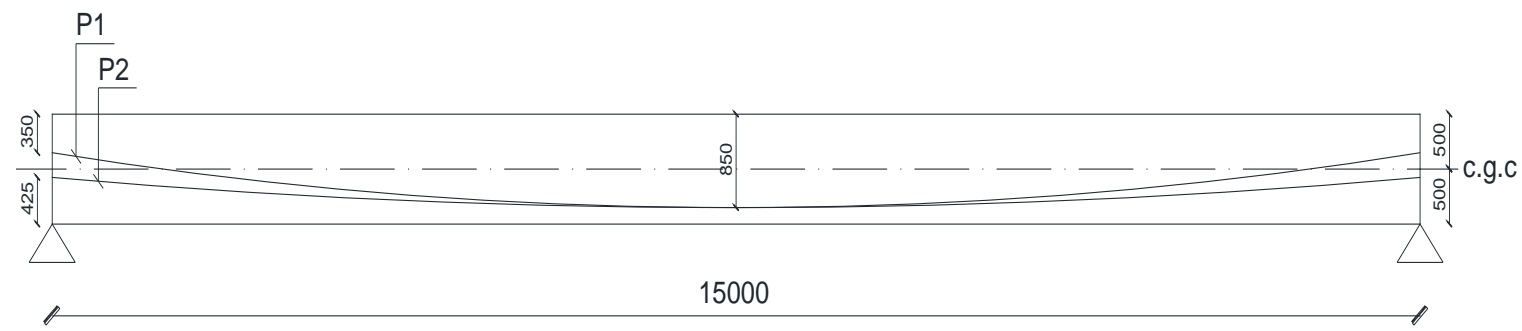

Gambar 4. Pemodelan tendon pada balok prategang

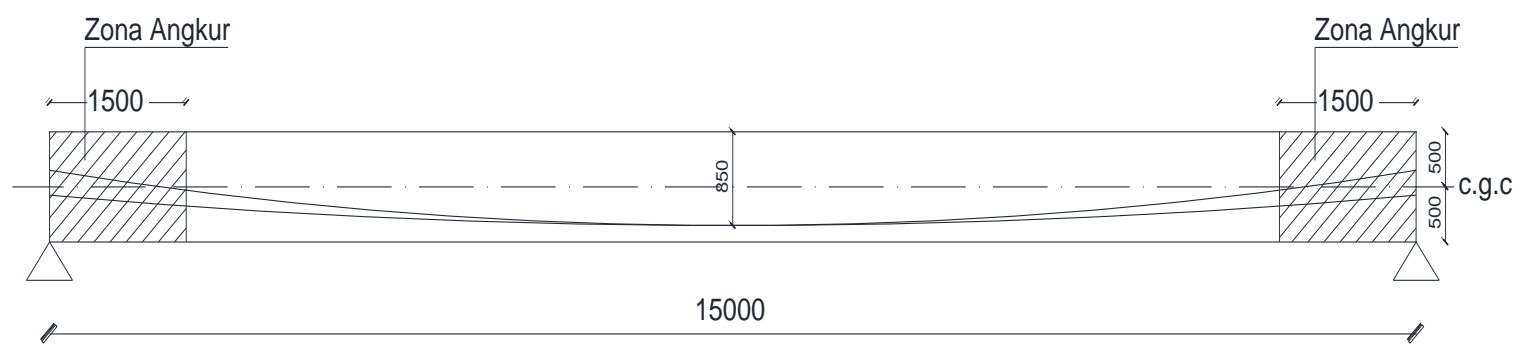

Gambar 5. Zona angkur pada balok prategang

\section{Analisis struktur dengan program MIDAS FEA 2016}

Untuk gaya yang terjadi di angkur, jacking force diubah menjadi gaya pressure merata sebesar luas ukuran bearing plate dengan perhitungan sebagai berikut:
Ukuran bearing plate 1
$=200 \mathrm{~mm} \times 200 \mathrm{~mm}$
Ukuran bearing plate 2
$=150 \mathrm{~mm} \times 150 \mathrm{~mm}$
Gaya pressure 1 (P1)
$=\frac{1570728,473}{200 \times 200}=39,2682 \mathrm{~N} / \mathrm{mm}^{2}$
Gaya pressure $2(\mathrm{P} 2)$

$$
=\frac{916258,276}{150 \times 150}=40,7226 \mathrm{~N} / \mathrm{mm}^{2}
$$




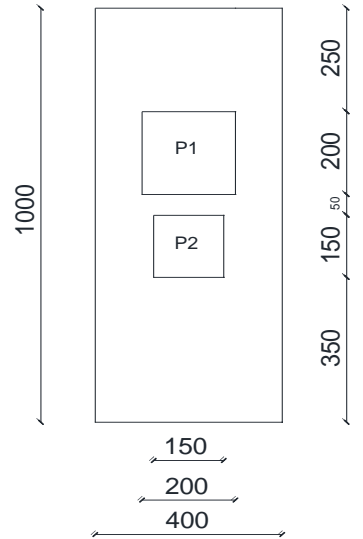

Gambar 6. Pemodelan bearing plate pada zona angkur

Analisis struktur zona angkur dilakukan dengan 3 tahapan, yaitu zona angkur yang diberi gaya P1, zona angkur yang diberi gaya P2, dan zona angkur yang diberi gaya P1 dan P2 secara bersama-sama yang hasilnya akan dibandingkan dengan P1 dan P2 yang di superposisi yang kemudian disebut sebagai P3.

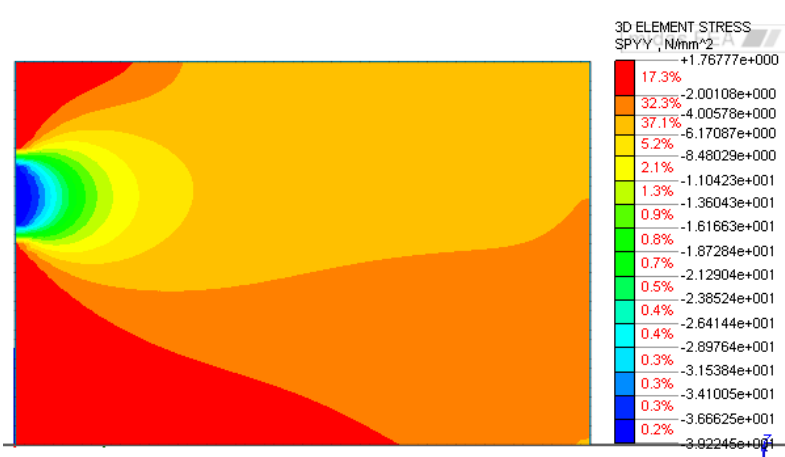

Gambar 7. Tegangan tekan akibat P1

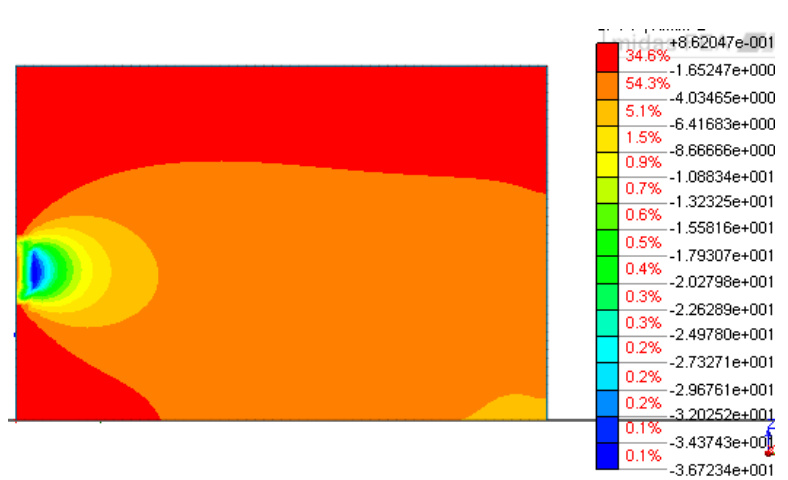

Gambar 9. Tegangan tekan akibat P2

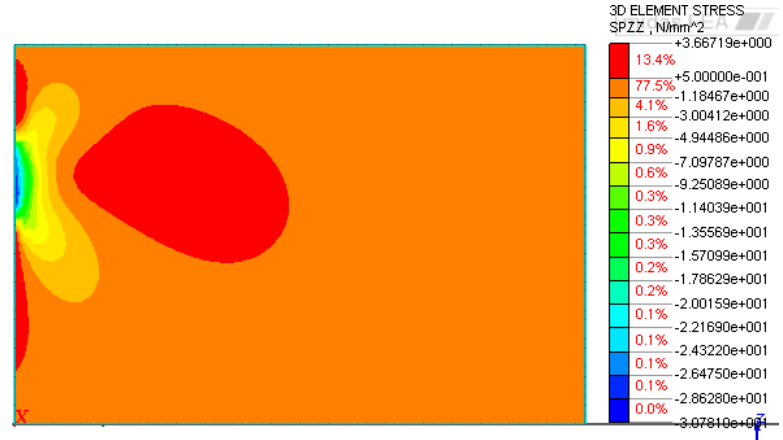

Gambar 8. Tegangan tarik akibat P1

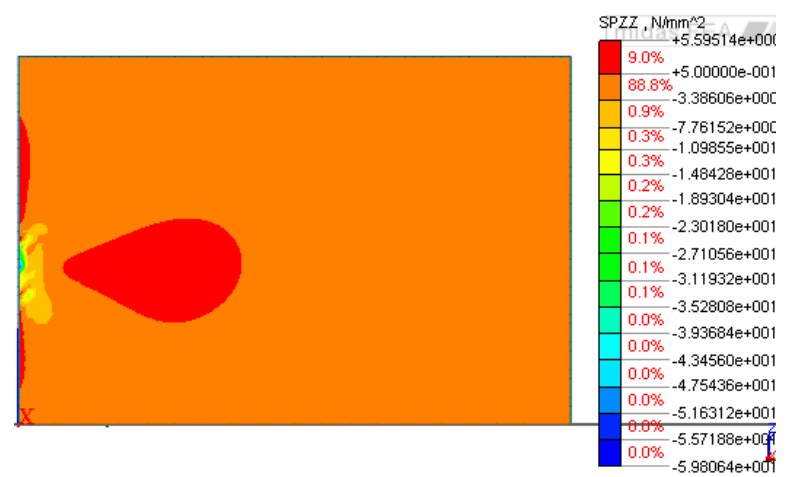

Gambar 10. Tegangan tarik akibat P2 
Analisis tegangan P1 dan P2 di superposisi sehingga kemudian didapatkan nilai grafik tegangan P3 sebagai berikut:

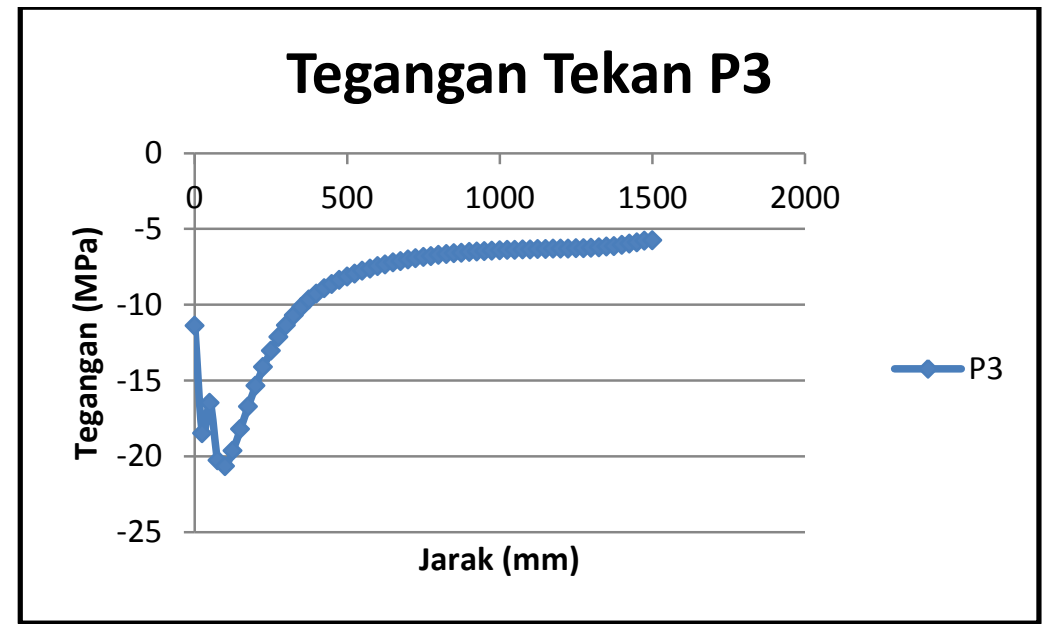

Gambar 11. Grafik tegangan tekan P3

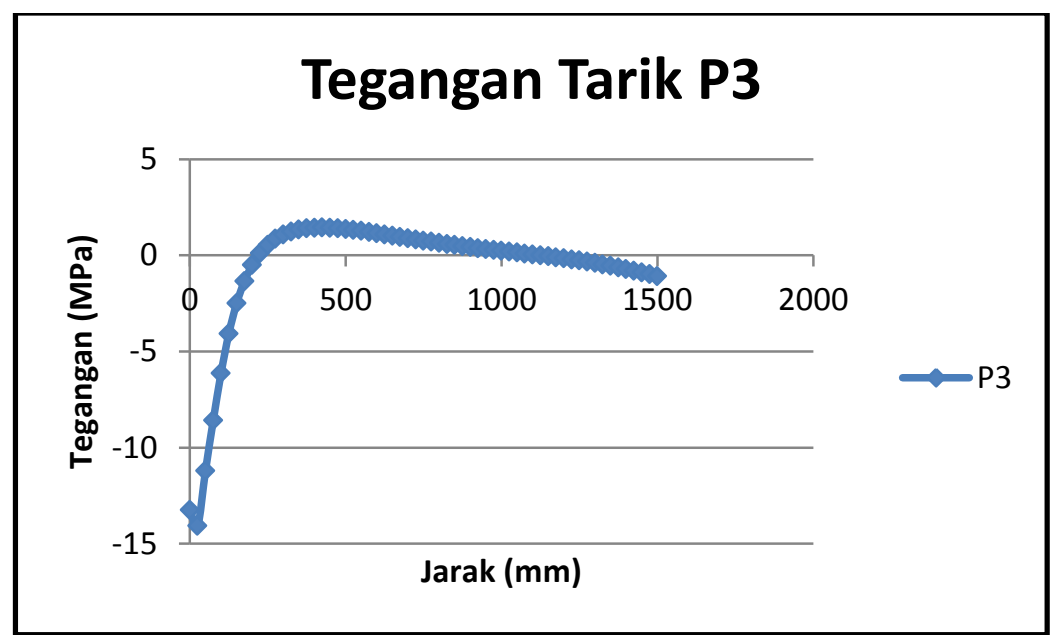

Gambar 12. Grafik tegangan tekan P3

Dilakukan analisis akibat gaya P1 dan P2 dan menghasilkan tegangan tekan dan tarik sebagai berikut:

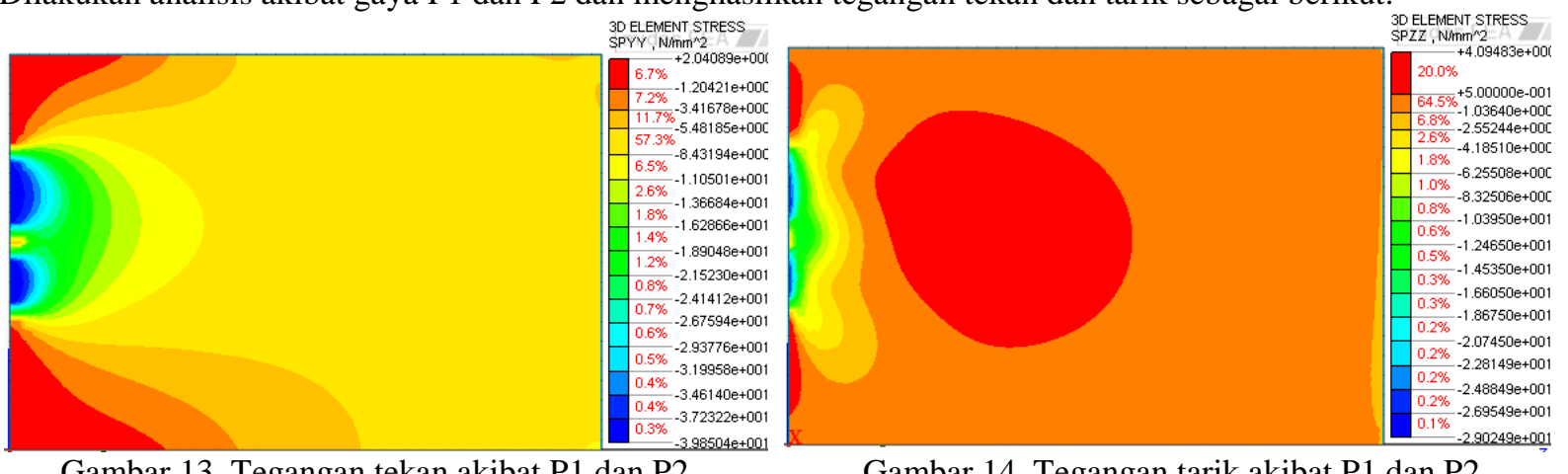

Gambar 13. Tegangan tekan akibat P1 dan P2

Gambar 14. Tegangan tarik akibat P1 dan P2 


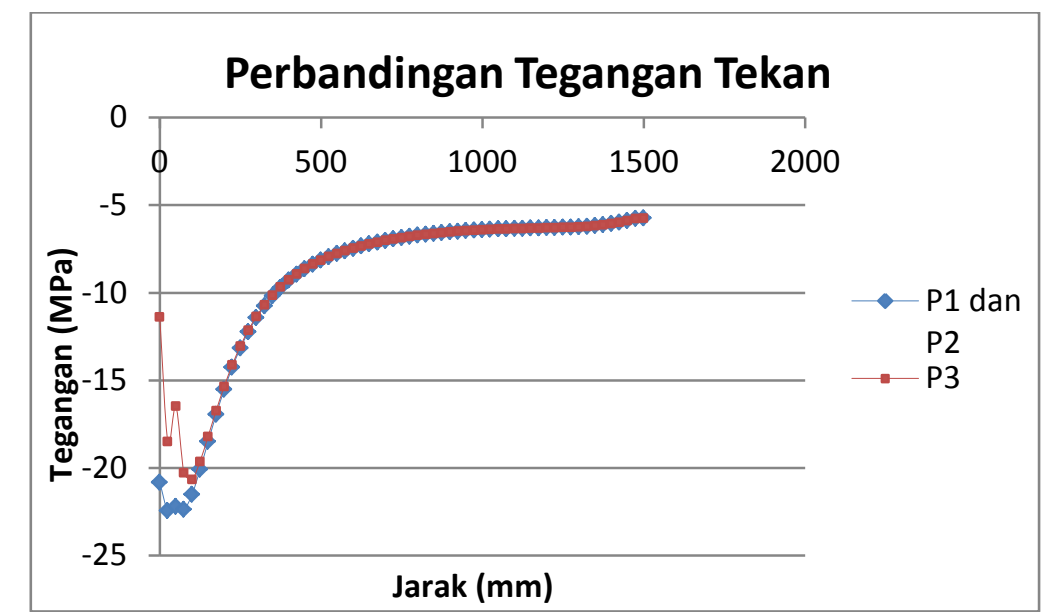

Gambar 15. Grafik perbandingan tegangan tekan antara P1 dan P2 dengan P3

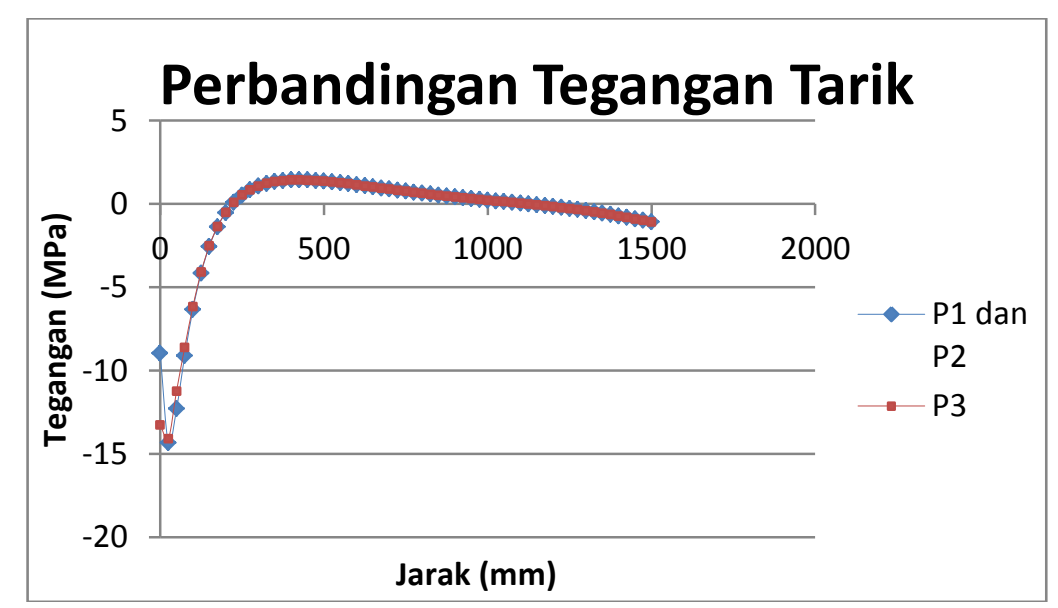

Gambar 16. Grafik perbandingan tegangan tarik antara P1 dan P2 dengan P3

Berdasarkan hasil analisis tegangan antara tegangan P1 dan P2 dengan tegangan P3, pada tegangan tekan dapat dilihat bahwa terjadi perbedaan yang signifikan pada koordinat 0 hingga koordinat 150 sedangkan pada tegangan tarik terdapat perbedaan yang cukup signifikan pada koordinat 0 hingga koordinat 50 . Tetapi analisis tegangan ini dapat dilakukan secara terpisah karena perbedaan yang besar hanya terjadi pada titik awal koordinat.

\section{Pemodelan dengan strut and tie}

Berdasarkan hasil analisis tegangan zona angkur pada MIDAS FEA 2016 v1.1 akibat gaya P1 dan P2, didapatkan daerah tarik dengan titik maksimum tarik pada koordinat 400 sehingga koordinat tersebut digunakan sebagai letak garis pengikat (tie).

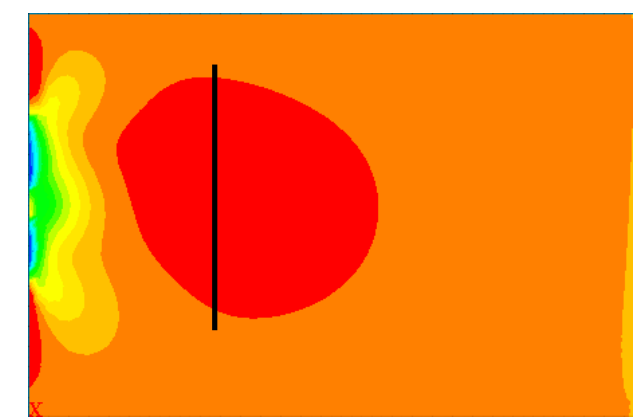

Gambar 17. Letak garis pengikat akibat P1 dan P2

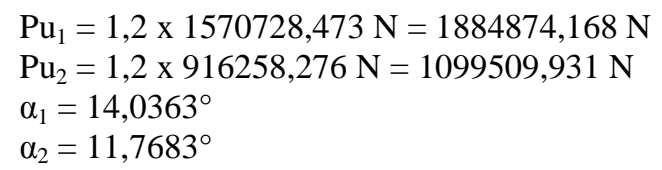




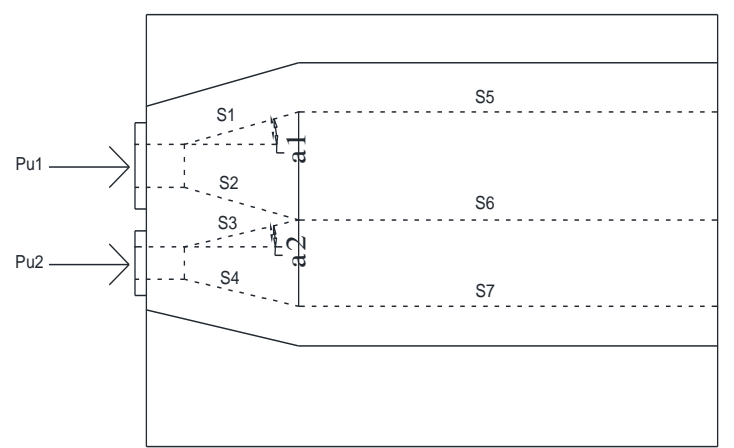

Gambar 18. Pemodelan Strut and Tie Akibat Gaya P1 dan P2

Tabel 1. Distribusi gaya pada strut and tie akibat gaya P1 dan P2

\begin{tabular}{cc}
\hline Member & Gaya $(\mathrm{kN})$ \\
\hline S1 & 971,4419 \\
\hline S2 & 971,4419 \\
\hline S3 & 561,5587 \\
\hline S4 & 561,5587 \\
\hline S5 & 942,4371 \\
\hline S6 & 1492,192 \\
\hline S7 & 549,755 \\
\hline T1 & 235,6092 \\
\hline T2 & 114,5323 \\
\hline
\end{tabular}

Luas baja untuk T1 dan T2

$A_{\text {stT } 1}=\frac{T}{\emptyset f y}=\frac{235,6092 \times 1000}{0,9 \times 460}=569,1044 \mathrm{~mm}^{2}$

$A_{\text {stT2 }}=\frac{T}{\emptyset f y}=\frac{114,5323 \times 1000}{0,9 \times 460}=276,6480 \mathrm{~mm}^{2}$

Digunakan 3 buah tulangan sengkang 2 kaki D $13 \mathrm{~mm}$.

$A_{s t}=\frac{1}{4} \pi D^{2}=\frac{1}{4} \pi \times 13^{2} \times 2 \times 3=796,3934 \mathrm{~mm}^{2}>\mathrm{A}_{\mathrm{stT} 1}$ dan $\mathrm{A}_{\mathrm{stT} 2}(\mathrm{OK})$

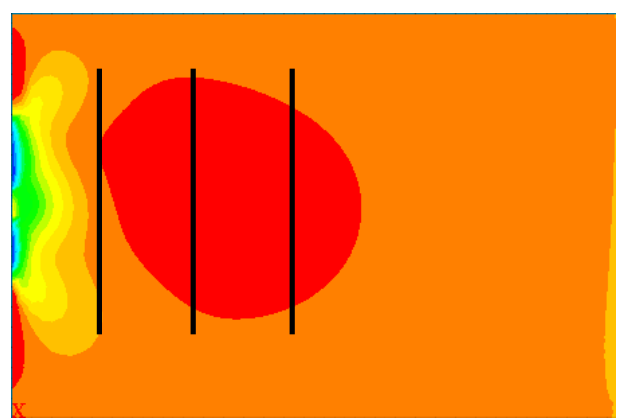

Gambar 19. Letak Tulangan Tarik Akibat Gaya P1 dan P2

Cek kapasitas struts dan nodes

Tabel 2. Luas daerah strut and tie akibat gaya P1 dan P2

\begin{tabular}{cccc}
\hline \multicolumn{4}{c}{ Cross Sectional Dimension } \\
\hline Member & Width $(\mathrm{mm})$ & Depth $(\mathrm{mm})$ & Acs $\left(\mathrm{mm}^{2}\right)$ \\
\hline S1 & 220 & 200 & 44000 \\
\hline S2 & 220 & 200 & 44000 \\
\hline S3 & 170 & 150 & 25500 \\
\hline S4 & 170 & 150 & 25500 \\
\hline S5 & 210 & 200 & 42000 \\
\hline S6 & 340 & 200 & 68000 \\
\hline S7 & 170 & 150 & 25500 \\
\hline T1 & 446 & 200 & 89200 \\
\hline T2 & 140 & 200 & 28000 \\
\hline
\end{tabular}


Perhitungan untuk S1,

$\varepsilon_{S}=\frac{P u_{\text {Tie }}}{A_{S t} E_{S}}=\frac{235,6092 \times 1000}{569,1044 \times 200000}=0,001479$

$\varepsilon_{1}=\varepsilon_{S}+\left(\varepsilon_{S}+0,002\right) \cot ^{2}\left(\alpha_{S}\right)=0,001479+(0,001479+0,002) \cot ^{2}(75,9638)=0,001697$

$f_{c u}=\frac{f^{\prime c}}{0,8+170 \varepsilon_{1}}=\frac{40}{0,8+170 \times 0,001697}=36,75 \mathrm{MPa}$

$0,85 f^{\prime} c=0,85 \times 40=34 \mathrm{MPa}, \mathrm{f}_{\mathrm{cu}}>0,85 \mathrm{f}^{\prime} \mathrm{c}$, digunakan $\mathrm{f}_{\mathrm{cu}}=34 \mathrm{MPa}$

$\varnothing \mathrm{Pn}=\varnothing \mathrm{f}_{\mathrm{cu}} \mathrm{A}_{\mathrm{cs}}=0,75 \times 34 \times 44000=1047,2 \mathrm{kN}>\mathrm{Pu}, \mathrm{S} 1$ memenuhi.

Tabel 3. Cek kapasitas strut akibat gaya P1 dan P2

\begin{tabular}{|c|c|c|c|c|c|c|c|c|c|}
\hline & $\mathrm{Pu}(\mathrm{kN})$ & Tie $(\mathrm{kN})$ & $\alpha \mathrm{s}$ & $\varepsilon S$ & $\varepsilon 1$ & $\mathrm{f}_{\mathrm{cu} 1}(\mathrm{MPa})$ & $\mathrm{f}_{\mathrm{cu}}$ pakai $(\mathrm{MPa})$ & $\varnothing \mathrm{Pn}(\mathrm{kN})$ & KET \\
\hline $\mathrm{S} 1$ & 971,441896 & \multirow{2}{*}{235,60921} & 75,96376 & 0,001479 & 0,001697 & 36,75001 & 34 & 1047,2 & $\mathrm{OK}$ \\
\hline S2 & 971,441911 & & 75,96376 & 0,001479 & 0,001697 & 36,75001 & 34 & 1047,2 & $\mathrm{OK}$ \\
\hline S3 & 561,558694 & \multirow{2}{*}{114,53229} & 78,23171 & 0,001215 & 0,001355 & 38,8232 & 34 & 606,9 & $\mathrm{OK}$ \\
\hline S4 & 561,558694 & & 78,23171 & 0,001215 & 0,001355 & 38,8232 & 34 & 606,9 & $\mathrm{OK}$ \\
\hline S5 & 942,437084 & \multirow{2}{*}{235,60921} & 90 & 0,001479 & 0,001479 & 38,04204 & 34 & 999,6 & $\mathrm{OK}$ \\
\hline S6 & 1492,19205 & & 90 & 0,001479 & 0,001479 & 38,04204 & 34 & 1618,4 & $\mathrm{OK}$ \\
\hline S7 & 549,754966 & 114,53229 & 90 & 0,001215 & 0,001215 & 39,73819 & 34 & 606,9 & $\mathrm{OK}$ \\
\hline
\end{tabular}

Node 5

Tipe nodal $=\mathrm{CCT}$

Untuk CCT, node $\mathrm{f}_{\text {cu }}=0,75 \mathrm{f}^{\prime} \mathrm{c}=0,75 \mathrm{x} 40=30 \mathrm{MPa}<\mathrm{f}_{\text {cu }}$, perlu di cek kapasitas node 5 .

Tabel 4. Cek tipe nodes akibat gaya $\mathrm{P} 1$ dan $\mathrm{P} 2$

\begin{tabular}{cccccc}
\hline & Strut $\mathrm{f}_{\text {cu }}(\mathrm{MPa})$ & Node & Node Type & Node $_{\text {cu }}(\mathrm{MPa})$ & KET \\
\hline $\mathrm{S} 1$ & 34 & 1 & CCC & 34 & \\
\hline & 34 & 5 & CCT & 30 & CHECK \\
\hline S2 & 34 & 1 & CCC & 34 & \\
\hline & 34 & 6 & CCT & 30 & CHECK \\
\hline S3 & 34 & 3 & CCC & 34 & \\
\hline & 34 & 6 & CCT & 30 & CHECK \\
\hline S4 & 34 & 4 & CCC & 34 & \\
\hline & 34 & 7 & CCT & 30 & CHECK \\
\hline S5 & 34 & 5 & CCT & 30 & CHECK \\
\hline S6 & 34 & 6 & CCT & 30 & CHECK \\
\hline S7 & 34 & 7 & CCT & 30 & CHECK \\
\hline
\end{tabular}

Node 5

$\varnothing \mathrm{Pn}=\varnothing \mathrm{f}_{\mathrm{cu}} \mathrm{A}_{\mathrm{cs}}=0,75 \times 30 \times 44000=990 \mathrm{kN}>\mathrm{Pu}, \mathrm{S} 1$ memenuhi, sehingga node 3 memenuhi.

Tabel 5. Cek kapasitas nodes akibat gaya P1 dan P2

\begin{tabular}{|c|c|c|c|c|c|c|}
\hline Node & $\mathrm{f}_{\mathrm{cu}}(\mathrm{MPa})$ & Join & $\mathrm{A}_{\mathrm{cs}}\left(\mathrm{mm}^{2}\right)$ & $\mathrm{Pu}(\mathrm{kN})$ & $\varnothing \operatorname{Pn}(\mathrm{kN})$ & \\
\hline \multirow{3}{*}{5} & 30 & $\mathrm{~S} 1$ & 44000 & 971,4419 & 990 & $\mathrm{OK}$ \\
\hline & 30 & S5 & 42000 & 942,4371 & 945 & $\mathrm{OK}$ \\
\hline & 30 & $\mathrm{~T} 1$ & 89200 & 235,6092 & 2007 & $\mathrm{OK}$ \\
\hline \multirow{5}{*}{6} & 30 & S2 & 44000 & 971,4419 & 990 & $\mathrm{OK}$ \\
\hline & 30 & S3 & 25500 & 561,5587 & 573,75 & $\mathrm{OK}$ \\
\hline & 30 & S6 & 68000 & 1492,192 & 1530 & $\mathrm{OK}$ \\
\hline & 30 & $\mathrm{~T} 1$ & 89200 & 235,6092 & 2007 & $\mathrm{OK}$ \\
\hline & 30 & $\mathrm{~T} 2$ & 28000 & 114,5323 & 630 & $\mathrm{OK}$ \\
\hline \multirow{3}{*}{7} & 30 & S4 & 25500 & 561,5587 & 573,75 & $\mathrm{OK}$ \\
\hline & 30 & S7 & 25500 & 549,755 & 573,75 & $\mathrm{OK}$ \\
\hline & 30 & $\mathrm{~T} 2$ & 28000 & 114,5323 & 630 & OK \\
\hline
\end{tabular}

Penulangan arah vertikal:

$\mathrm{s}=200 \mathrm{~mm} ; \mathrm{b}=400 \mathrm{~mm} ; \mathrm{A}_{\text {st crack }}=0,003 \times 200 \times 400=240 \mathrm{~mm}^{2}$

Digunakan tulangan sengkang 4 kaki D $13 \mathrm{~mm}$ 
$\mathrm{A}_{\mathrm{st}}=1 / 4 \pi \mathrm{D}^{2}=1 / 4 \pi \times 13^{2} \times 4=530,9292 \mathrm{~mm}^{2}$

Penulangan arah horizontal:

$\mathrm{s}=100 \mathrm{~mm} ; \mathrm{b}=400 \mathrm{~mm} ; \mathrm{A}_{\text {st crack }}=0,003 \times 150 \times 400=120 \mathrm{~mm}^{2}$

Digunakan tulangan longitudinal 4 D $10 \mathrm{~mm}$

$\mathrm{A}_{\mathrm{st}}=1 / 4 \pi \mathrm{D}^{2}=1 / 4 \pi \times 10^{2} \times 4=314,1593 \mathrm{~mm}^{2}$

Spalling force $=2 \% \mathrm{Pu}=0,02 \times(1884874,168+1099509,931)=59687,682 \mathrm{~N}$

Luas tulangan untuk menahan spalling force $\left(\mathrm{A}_{\mathrm{st}}\right)=\frac{P}{\emptyset f y}=\frac{59687,682}{0,9 \times 460}=144,1731 \mathrm{~mm}^{2}$

Digunakan tulangan sengkang grid D $10 \mathrm{~mm}$

$\mathrm{A}_{\mathrm{st}}=1 / 4 \pi \mathrm{D}^{2}=1 / 4 \pi \times 10^{2} \times 4=314,1592 \mathrm{~mm}^{2}>144,1731 \mathrm{~mm}^{2}(\mathrm{OK})$

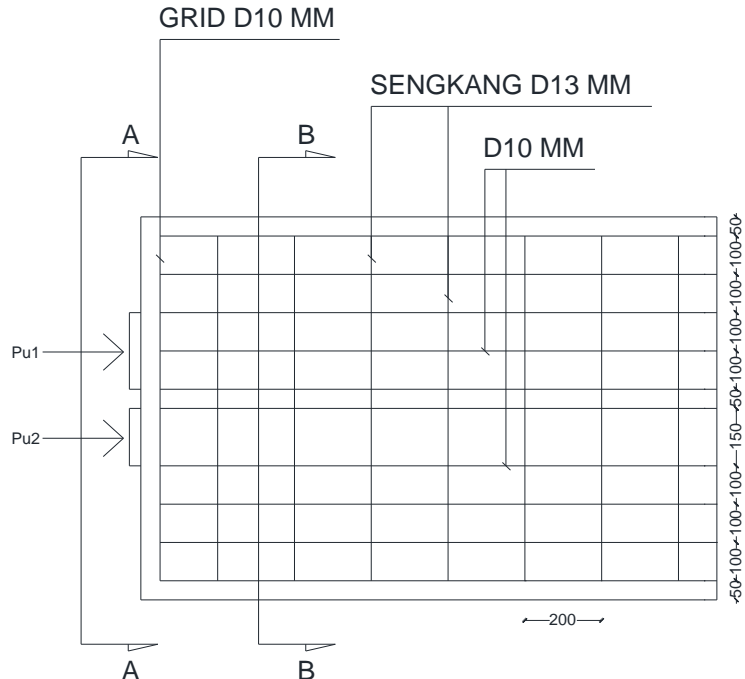

Gambar 20. Tampak samping zona angkur ganda

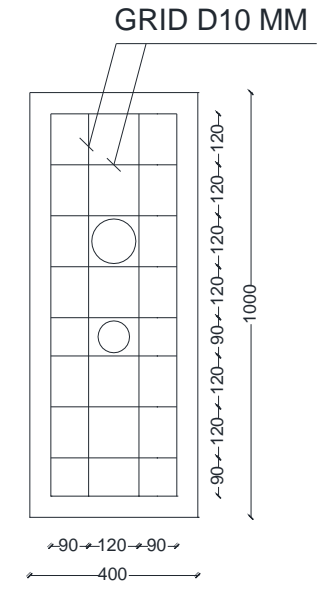

Gambar 21. Potongan A-A

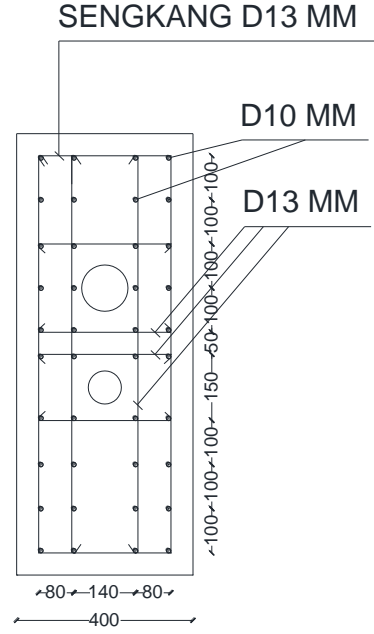

Gambar 22. Potongan B-B

\section{KESIMPULAN}

Berdasarkan analisis yang telah dilakukan, didapatkan beberapa kesimpulan sebagai berikut:

1. Zona angkur pada daerah tekan menimbulkan tegangan tarik pada arah lateral. Tegangan tarik yang terjadi pada zona angkur perlu diatasi dengan bursting steel.

2. Pada daerah tepi balok terjadi tegangan spalling yang perlu diatasi dengan spalling reinforcement.

3. Pada balok dengan angkur ganda, tegangan tarik mulai terjadi pada jarak $225 \mathrm{~mm}$ dan tegangan tarik maksimum terjadi pada jarak $425 \mathrm{~mm}$ sebesar 1,446 MPa.

4. Analisis tegangan dengan dua angkur antara masing-masing gaya dapat dilakukan secara terpisah karena hasil menunjukkan analisis tegangan yang dilakukan secara terpisah dengan yang digabungkan menunjukkan hasil yang sama.

\section{DAFTAR PUSTAKA}

AASHTO. (2002). Standard Specifications for Highway Bridges. Washington DC: American Association of State Highway and Transportation Officials.

AASHTO. (2012). AASHTO LRFD Bridge Design Specifications. Washington DC: American Association of State Highway and Transportation Officials.

ACI Committee 318. (2007). Building Code Requirements for Structural Concrete (ACI 318-08) and Commentary. USA: American Concrete Institute.

Breen, J.E. dkk. (1994). Anchorage Zone Reinforcement for Post-Tensioned Concrete Girders. Washington DC: Transportation Research Board.

Lin, T.Y. dan Ned H. Burns. (1981). Design of Prestressed Concrete Structures. Canada: John Wiley \& Sons.

Logan, Daryl L. (2012). A First Course in the Finite Element Method Fifth Edition. Stamford: Cengage Learning.

Martin, Barney T. dan David H. Sanders. (2007). Verification and Implementation of Strut-and-Tie Model in LRFD Bridge Design Specifications. New York.

Rogowsky, D M. dan P Marti. (1996). Detailing for Post-Tensioned. Switzerland: VSL International Ltd. 